\title{
Diversity of vascular plant communities along a disturbance gradient in a central mid-hill community forest of Nepal
}

\begin{abstract}
S. K. Baral ${ }^{1}$ and K. Katzensteiner ${ }^{2}$
The 'Community Forestry Program' has been considered successful in improving the environmental situation in the hills of Nepal by enhancing the vegetation coverage of degraded sites and by improving the supply of forest products to farmers. The restoration measures are considered sustainable if the ecosystems are self-supporting and resilient against perturbation. A community forest (CF) in the mid-hills of Nepal has been assessed for restoration success based on the comparison of vegetation structure and species diversity along a disturbance gradient, using a semi-protected natural forest as a reference site. In general, the community forest management (CFM) was able to re-establish forests on formerly severely degraded sites. Forest operations carried out during CFM have altered plant community composition, species richness and distribution, age class distribution of trees and vegetation structure. As a result, the CF was being transformed into a less diverse regular forest although the overall vascular plant diversity was retained with sufficient niches within the understorey vegetation.
\end{abstract}

Keywords: Central mid-hills, community forest, disturbance regimes, Nepal, plant diversity

C mmunity Forestry $(\mathrm{CF})$ has proved to be an fficient approach in the forestry sector of Nepal. In the mid-hills, it is credited with improving people's livelihoods and conserving natural landscapes (Satyal, 2004). Also the CF program is noted for in increasing the vegetation coverage (greenery) of degraded sites, fostering local level institutions for resource management, improving the supply of forest products to farmers, and correcting the environmental situation in the hills of Nepal (Acharya, 2003).

The agricultural system in Nepal relies on the interdependence of arable land and livestock with forests (Satyal, 2004). In the hills of Nepal, farmers rely heavily on forest litter that is collected for animal bedding and then enriched with animal excrement to be incorporated as compost into the agricultural system. In this kind of interlinked hill farming system, CF has strived to supply forest products to local users and while conserving biodiversity with silvicultural techniques such as cleaning, weeding, thinning and pruning.

Padma (2007) reported that CF had positive impacts on biodiversity conservation by increasing the vegetation cover and the number of wildlife species, thereby averting the local extinction of species. However, his study revealed that CFUGs tended to conserve only "useful" species i.e. low-quality timber trees, shrubs, climbers, grasses and herbs were removed, a practice that could have undesirable implications on biodiversity. Such implications include a changed community structure, a reduction of understorey species, and even age stands with low biodiversities. The present case study tests a methodological approach for comparing and analyzing the impacts of silvicultural techniques and biomass extraction from community forests on vascular plant diversity. The investigations were carried out along a disturbance gradient in a CF in the central mid-hills of Nepal.

\section{Materials and methods}

\section{Study site}

The study was carried out in Dhulikhel, the district headquarter of the Kavrepalanchowk District, $30 \mathrm{~km}$ east of Kathmandu. The district covers an area of 140,486 hectares and stretches between $85^{\circ} 24^{\prime}$ $85^{\circ} 49^{\prime} \mathrm{E}$ longitude and $27^{\circ} 20^{\prime}-27^{\circ} 85^{\prime} \mathrm{N}$ latitude in the central mid-hill region. It has been one of the

\footnotetext{
Assistant Research Officer, Department of Forest Research and Survey, Babarmahal, Kathmandu, Nepal e-mail: sharadbaral@gmail.com

2 Assoc.Prof., Institute of Forest Ecology, Department of Forest and Soil Science, University of Natural Resources and Applied Life Sciences, Vienna, Austria
} 
pioneer districts for the implementation of the community forestry program (Sharma 2000), a fact that provides an opportunity to interact with experienced forest user groups who have been involved for over 15 years in community forestry management activities (Humagain 2003). Moreover, the impacts of forest management activities on vascular plant diversity can be pronounced. The 'Gaukhureshwar Community Forest' (hereafter CF) and an adjoining semi-protected natural forest (Thulo ban) owned by the Dhulikhel Municipality (hereafter MF) have been selected for the study. The forests share similar climatic conditions, topographic features and belong to the same vegetation zone (Webb and Gautam, 2001).

\section{History of the forests}

Historically, the study site was a dense forest till 1933. Afterwards, the forest was gradually exploited. A series of natural calamities (earth quake, heavy rainfall) had disturbed the forest. Additional pressures from population growth and urbanization have led to severe degradation. Apparently, both the $\mathrm{CF}$ and MF were subjected to exploitation after 1934 to 1962. However, it is not clear which one of the two was more exploited in terms of resources (Webb and Gautam, 2001). Although the forests were classified as $\mathrm{CF}$ and MF based on the rights of management and utilization, the land ownership of both forests remained with the Government of Nepal, according to the Forest Act 1993.

\section{Gaukhureshwar community forest (CF)}

By 1981 the forest had been almost cleared for grazing pasture and only a few trees and bushes remained. In 1985 the local people made an effort to restore their forest by applying for support from the District Forest Office, Kabhre for enrichment planting with Pinus roxburgbii and to employ a forest watcher. Later on, the District Forest Office, Kabhre formally handed over 21 ha of this forest to the local people, thereby formulating a forest user group in 1992. Subsequently, secondary succession ensued (Webb and Gautam, 2001) and Pinus roxburgbii was outcompeted. The stands were about 20 years old by 2007 . Now the forest user group is managing this forest as a community forest and applying silvicultural techniques, according to their operational plan (Personal communication with the head of the CFUG Badri Jangam, 2007).

\section{Dhulikhel municipality owned forest (MF)}

The remaining patch of the forest (Thulo Ban) has been protected by the residents of Dhulikhel city since 1962 in order to conserve the watershed. After the establishment of the Dhulikhel Municipality in 1986, an important contribution to the protection of MF was the deployment of watchmen. No utilization activities had taken place since then (Webb and Gautam, 2001).

\section{Data collection}

\section{Sampling design}

A CF and a MF were selected for the field survey in comparable topographic positions. The diversity status of vascular plants and forest structure were compared between forest areas facing a high pressure of biomass extraction through the community forest management activities (CF) and the better protected municipality owned forest, facing little anthropogenic pressure (MF) as a reference site. Cleaning, thinning, pruning and litter raking activities had been carried out in the CF. Although the collection of forest products in MF had not been allowed, there had been some illegal collection of forest products (such as dry branches, tree stumps and litter in some plots).

A transect survey from the base to the top of the hill was conducted systematically to collect the primary data of each forest (CF and MF). In this transect, the survey was carried out in 8 systematically placed square-shaped composite plots of $10 \mathrm{~m} \times 10 \mathrm{~m}$ for poles, $5 \mathrm{~m} \times 5 \mathrm{~m}$ for shrubs and regeneration, and $1 \mathrm{~m} \times 1 \mathrm{~m}$ for herbs, a design which is a standard for contemporary community forest inventory in Nepal. The sample plots were located at least $50 \mathrm{~m}$ apart and at least $20 \mathrm{~m}$ interior from the edges or roads. After conducting a rapid forest survey, the required number of sample plots to reach a confidence interval for the average weight of biomass in the CF of $10 \%$ was calculated by using the following formula:

Number of plots $(\mathrm{n})=(\mathrm{t} * 100 * \mathrm{~S} / \mathrm{W} * \mathrm{e} \%)^{2}$

Whereby

$$
\begin{aligned}
\mathrm{t}= & \text { tabulated value of student } \mathrm{t}_{\mathrm{DF}-\mathrm{n}-1,1,} \\
& \mathrm{p}=0.05, \\
\mathrm{DF}= & \text { degrees of freedom } \\
\mathrm{S}_{\mathrm{x}}= & \text { standard deviation of biomass } \\
\mathrm{W}= & \text { Average weight of biomass } \\
\mathrm{e}= & \text { required accuracy [\%] }
\end{aligned}
$$




\section{Forest inventory}

Tree height, diameter at breast height (DBH) and crown width were measured for each plot. A clinometer was used for measuring tree height, and a D-tape and a measuring tape were used for the determination of $\mathrm{DBH}$ and crown width (diameter), respectively. The number of species in the understorey was recorded. The amount of litter left on the forest floor was estimated from $30 \mathrm{~cm} \times 30$ $\mathrm{cm}$ plots. By interviewing the FUG members, the quantity of litter collected from the CF was estimated.

\section{Scaling the disturbance}

To compute the simple plant community-based indices (plant diversity indices) of forest disturbance, the level of disturbance was scaled from 1-4 in an ordinal scale, where 1 is the lowest and 4 is the highest level of disturbance, based on the visual observation of sample plots on the basis of the amount of litter left on the forest floor, trampling and tree lopping and felling (Table 1).

\section{Secondary data}

Records of the forest management activities and the data related to the amount of forest products harvested/collected were drawn from the community forest user group's office and District Forest Office records.

\section{Data analysis}

Calculation of above ground biomass, basal area and diversity indices

The total above ground tree biomass was calculated by using the biomass table prepared by Tamrakar (1999). Basal area was calculated by using equation 4 below. Three biodiversity indices for the vascular plant diversity were calculated from the information of the forest inventory. Shannon Wiener Index was used as the index affected by both the number of species and the evenness of their population. This index increases as both values (number of species and evenness) increase. On the other hand, the Simpson's index was used as a dominance index. It is weighted towards the abundance of the most common species and measures the probability of two individuals randomly selected from a sample belonging to the same category. In this measure, as the index goes up, so does diversity.

The following formulae were used to calculate the diversity indices (Timberline Forest Inventory Consultants Ltd, 2003).

Shannon-Wiener index $\mathbf{H}=-\sum_{i=1}^{s} p_{i} \times \log p_{i} \ldots .1$

Simpson's diversity $\mathbf{D}=1-\sum_{i=1}^{s} p_{i}{ }^{2}$

Evenness $\mathbf{E}=\mathbf{H} / \log (\mathbf{N}$............................. 3

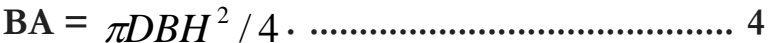

Where:

$$
\begin{aligned}
\mathrm{s}= & \text { number of species } \\
\mathrm{p}_{\mathrm{i}}= & \text { proportion of the } \mathrm{i}^{\text {th }} \text { species in a } \\
& \text { community } \\
\mathrm{N}= & \text { total number of species } \\
\mathrm{DBH}= & \text { diameter at breast height }(1.3 \mathrm{~m}) \\
& \text { from the ground level }
\end{aligned}
$$

\section{Statistical analysis}

Descriptive statistics was used to describe stand structure, forest composition and forest management activities. The differences between diversity indices of the different forest types were subjected to a Mann-Whitney U test because these parameters were not normally distributed. Basal area per hectare, number of plants in the understorey per hectare and estimated above ground biomass were subjected to independent sample t-tests. The level of significance used was $\alpha=0.05$.

\section{Results and discussions}

Forest management history, forest structure

\begin{tabular}{|c|c|c|c|c|c|c|}
\hline \multirow{2}{*}{ S.N. } & \multirow{2}{*}{ Criteria } & \multicolumn{4}{|c|}{ Score } & \multirow{2}{*}{ Overall score } \\
\hline & & 1 & 2 & 3 & 4 & \\
\hline 1 & $\begin{array}{l}\text { Amount of litter left on the } \\
\text { forest floor (Litter raking) }\end{array}$ & $>70 \%$ & $50-70 \%$ & $30-50 \%$ & $<30 \%$ & $\begin{array}{l}\text { The overall score of } \\
\text { the plot is: if the total }\end{array}$ \\
\hline 2 & Trampling & Low & Medium & High & Very high & scores \\
\hline 3 & Tree lopping and felling & Few & Medium & High & Very High & $\begin{array}{c}9-12=4,6-9=3,3- \\
6=2 \text { and }<3=1 .\end{array}$ \\
\hline
\end{tabular}
and diversity of vascular plants

Forest type and management activities

The forest vegetation type belonged to the boundary line between the sub-tropical Schima-Castanopsis

Table 1: Criteria for scaling the disturbance 
forest and the lower temperate forest. Major species found in the forest were: Castanopsis tribuloides, Quercus glauca, Rhododendron arboreum, Myrica esculenta, Myrsinia rivularis and Schima wallichii etc.

Litter raking was the dominant method of biomass extraction activities from the forest. Cleaning (removal of unwanted shrubs and weeds and singling of desired species) and thinning/pruning were the other silvicultural operations undertaken after the forest was handed over to the community. The intensity of thinning entirely depended on traditional knowledge. In this system, only the dead, dying, crooked, malformed and weak trees were preferentially removed. On average, $30 \%$ of polesized trees were removed in the thinning operations and the branches were pruned up to $50 \%$ of tree height. During winter, litter raking has been free for the users. Grazing and illegal collection of forest products were totally prohibited. Table 2 displays the record of quantity of biomass extracted at different time periods from the community forest.

\section{Forest structure}

The MF had a higher stem density per hectare. However, the understorey density was higher in CF. In the MF, basal area was almost double that of $\mathrm{CF}$, and the estimated above ground biomass was also slightly higher. Similarly, both the maximum tree height $(13.5 \mathrm{~m})$ and the maximum DBH $(29.5 \mathrm{~cm})$ were significantly higher in MF (Table 4).

A larger part of the basal area in the MF was occupied by the trees with higher diameters but in the CF the larger part of the basal area was contributed by trees with 5-15 cm DBH since there were no trees thicker than $20 \mathrm{~cm} \mathrm{DBH}$ (Fig 1).

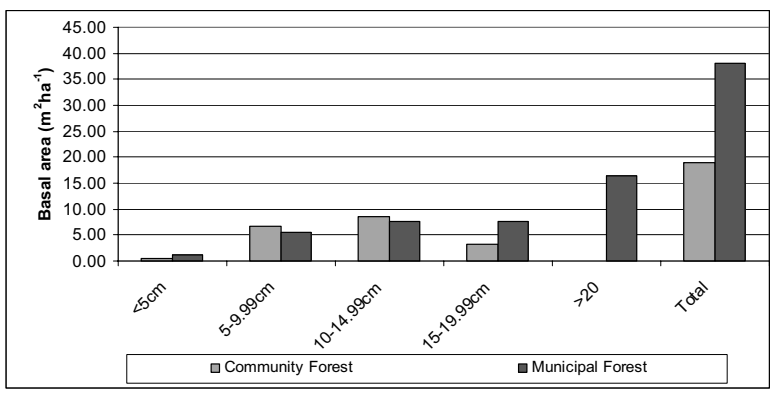

Figure 1: Basal area distribution in different $\mathrm{DBH}$ classes

Castanopsis tribuloides and Quercus glauca were the major dominating tree species in CF occupying the higher share (almost $80 \%$ ) of the total basal area, whereas the basal area was distributed rather fairly among all the species that were found in the site in MF (Fig 2).

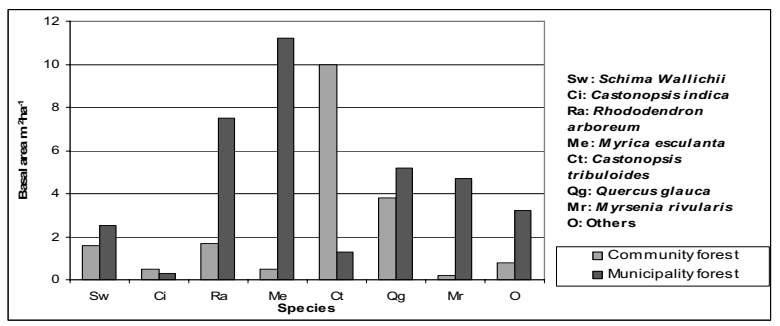

Figure 2: Basal area distribution of tree species in the $\mathrm{CF}$ and MF

The average biomass in the MF was $17.61 \mathrm{~kg} \mathrm{~m}^{-2}$, $\mathrm{SE}=0.91$, a sum significantly higher than the average biomass of the CF $\left(12.08 \mathrm{~kg} \mathrm{~m}^{-2}, \mathrm{SE}=0.86\right)$. In the $\mathrm{CF}$, almost $85 \%$ of the biomass was contributed by two major tree species Castanopsis tribuloides and

Table 2: Community forest management activities and quantity of forest biomass extracted

\begin{tabular}{|c|c|c|c|c|c|}
\hline \multirow{2}{*}{ S.N. } & \multirow{2}{*}{ Year } & \multirow{2}{*}{ Management activities } & \multicolumn{3}{|c|}{ Forest product extraction } \\
\hline & & & Product & Unit* & Quantity \\
\hline 1 & 1993 & Cleaning & Fuelwood with green foliage & $\mathrm{Mg} \mathrm{ha}^{-1}$ & 3.7 \\
\hline 2 & 1994 & Cleaning & Fuelwood with green foliage & $\mathrm{Mg} \mathrm{ha}^{-1}$ & 2.8 \\
\hline \multirow[t]{3}{*}{3} & 1997 & Thinning/pruning & Fuel-wood & $\mathrm{m}^{3} \mathrm{ha}^{-1}$ & 1.2 \\
\hline & & (Average thinning intensity $=30 \%$ ) & Timber & $\mathrm{m}^{3} \mathrm{ha}^{-1}$ & 0.4 \\
\hline & & & Foliage & $\mathrm{Mg} \mathrm{ha}^{-1}$ & 0.3 \\
\hline 4 & 1999 & Cleaning & Fuelwood with green foliage & $\mathrm{Mg} \mathrm{ha}^{-1}$ & 6.8 \\
\hline 5 & Annually & Litter raking ( $82 \%$ of the total litter) & Litter & $\mathrm{Mg} \mathrm{ha}^{-1}$ & 3.2 \\
\hline
\end{tabular}

* The unit was calculated considering 1 bhari $=40 \mathrm{~kg}$ for green foliage and fire wood and 1 bhari litter $=25 \mathrm{~kg}$ of litter

Table 3: Density, basal area and estimated above ground biomass in different forest types

\begin{tabular}{|c|c|c|c|c|c|c|}
\hline Forest type & $\begin{array}{c}\text { Basal area } \\
\mathrm{m}^{2} \mathrm{ha}^{-1}\end{array}$ & $\begin{array}{c}\text { No. of stems } \\
\text { ha }^{-1}\end{array}$ & $\begin{array}{c}\text { No. of plants in } \\
\text { the understorey } \\
\qquad h^{-1}\end{array}$ & $\begin{array}{l}\text { Max. tree } \\
\text { height } \\
\text { (m) }\end{array}$ & $\begin{array}{c}\text { Max } \\
\text { DBH } \\
(\mathrm{cm})\end{array}$ & $\begin{array}{c}\text { Estimated above } \\
\text { ground biomass } \\
\left(\mathrm{kg} \mathrm{m}^{-2}\right)\end{array}$ \\
\hline $\mathrm{CF}$ & $19.03^{a}$ & 2525 & $7050^{\mathrm{a}}$ & 12.5 & 16.5 & $12.18^{\mathrm{a}}$ \\
\hline $\mathrm{MF}$ & $38.19^{a}$ & 2725 & $4850^{\mathrm{a}}$ & 13.5 & 29.5 & $17.72^{\mathrm{a}}$ \\
\hline
\end{tabular}

${ }^{a}$ Significant difference between CF and MF in independent samples t-test at á=0.05. 
Quercus glanca but in the MF the biomass was distributed among the wider species composition typical to this forest type (Fig 3). This observation suggests a tendency for species preference among forest users in community forest management. They probably preserved preferred species (Castanopsis tribuloides and Quercus glauca) and removed others. In the $\mathrm{CF}$, they had also removed bigger and older trees during silvicultural operations to provide space for a future crop of younger trees of the preferred species.

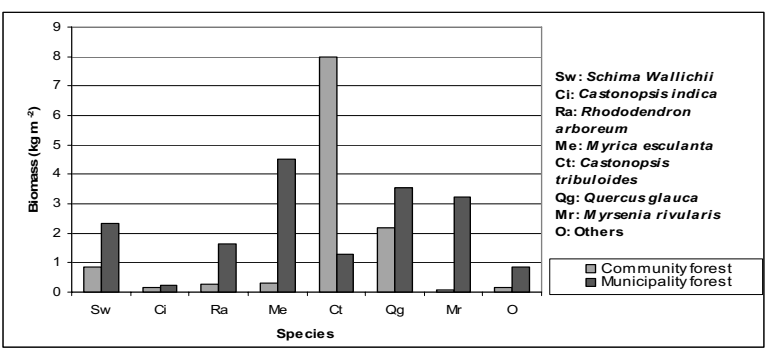

Figure 3: Biomass distribution of tree species in the $\mathrm{CF}$ and MF

Species richness, abundance and diversity indices

The cumulative tree species number increased with the increasing number of plots. The number of understorey species rapidly increased in the initial plots but the increase declined after the fifth plot for both forests. The slope of the curve for understorey flattened after five to six plots (Fig 4).

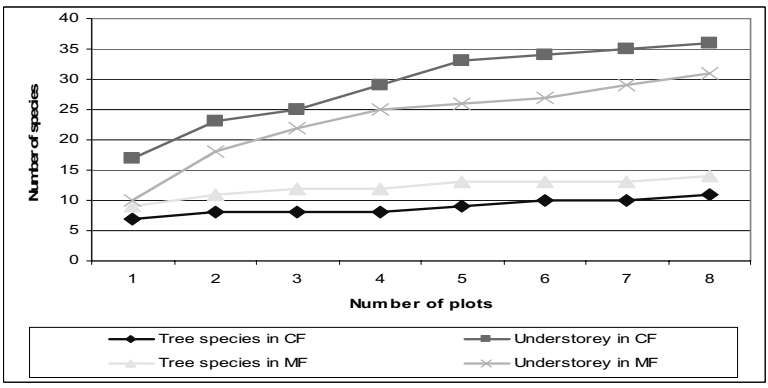

Figure 4: Cumulative number of species
From this pattern it can be concluded that the number of plots was sufficient to describe the diversity within the two forest types.

There were 40 vascular plant species of 30 families found in the CF but in the MF only 36 species of 25 families were recorded. The number of tree species was slightly higher in the MF (14 species of 10 families) than that of the CF (11 species of 8 families) (Annex 1). The diversity index for the tree layer in the CF was 0.96 for Shannon Wiener, 0.48 for Simpson and 0.6 for Evenness, as opposed to 1.6 for Shannon Wiener, 0.75 for Simpson and 0.85 for Evenness in the MF. This result underscored the higher tree species richness and their more even distribution within the MF than in the CF (Table 4).

While the tree layer diversity was significantly higher in the MF than in the $\mathrm{CF}$, the understorey vegetation diversity was slightly higher in the CF, although this difference was insignificant (Table 4).

Castanopsis tribuloides and Quercus glauca were the most abundant tree species found in the CF, whereas Myrsinia rivularis, Quercus glauca, Rhododendron arboreum and Myrica esculenta were the species having a higher abundance in the MF (Fig 5).

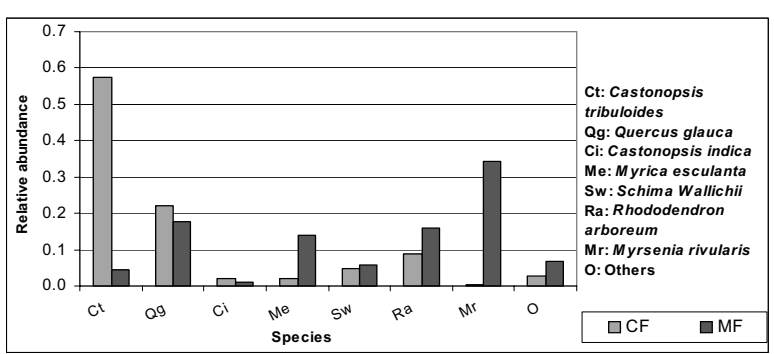

Figure 5: Abundance of different tree species in CF and MF

Table 4: Number of families and species in forest, Shannon Wiener diversity index, Simpson's index and Evenness at study sites

\begin{tabular}{|c|c|c|c|c|c|c|}
\hline $\begin{array}{c}\text { Forest type } \\
\text { / Layer }\end{array}$ & $\begin{array}{c}\text { Number of } \\
\text { species }\end{array}$ & $\begin{array}{c}\text { Total } \\
\text { number of } \\
\text { families }\end{array}$ & $\begin{array}{l}\text { Shannon- } \\
\text { Wiener } \\
\text { Index (H) }\end{array}$ & $\begin{array}{l}\text { Simpson's } \\
\text { Index (D) }\end{array}$ & $\begin{array}{c}\text { Evenness } \\
\text { (E) }\end{array}$ & Remarks \\
\hline \multicolumn{7}{|l|}{$\overline{\mathrm{CF}}$} \\
\hline Tree layer & 11 & 8 & $0.96^{\mathrm{a}}$ & $0.48^{\mathrm{a}}$ & $0.60^{\mathrm{a}}$ & \\
\hline Under storey & 36 & 30 & 1.96 & 0.84 & 0.91 & \\
\hline Total & 40 & 30 & & & & \\
\hline \multicolumn{7}{|l|}{ MF } \\
\hline Tree layer & 14 & 10 & $1.6^{\mathrm{a}}$ & $0.75^{\mathrm{a}}$ & $0.85^{\mathrm{a}}$ & \\
\hline Under storey & 32 & 25 & 1.87 & 0.8 & 0.88 & \\
\hline Total & 36 & 25 & & & & \\
\hline
\end{tabular}

\footnotetext{
${ }^{a}$ denotes the significant difference between CF and MF in the Mann Whitney U test at $\alpha=0.05$.
} 


\section{Tree diversity indices according to different scale of disturbance}

The value of Shannon Wiener index and Simpson's index were plotted against the scale of disturbance in the plots. Fig 6 shows that when the intensity of disturbance increased from 1 to 2 , the tree diversity in the forest slightly increased but heavy disturbance (categories $>2$ ) was associated rapid decrease in diversity.

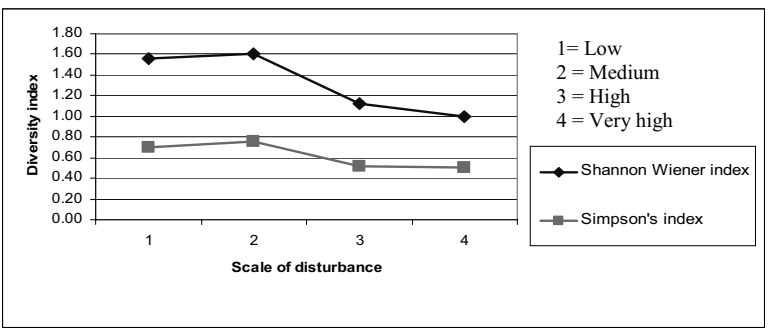

Figure 6: Value of diversity indices with respect to different scale of disturbance

This study indicated that the basal area per hectare, biomass and tree density were higher in the forest that was better protected (MF) than in the community forest. Species diversity in the tree layer was also higher in the MF. Forest biodiversity depends on even age class distribution, presence of various tree species and proper distribution of these species in the forest stand (HMG/N 2002). However, the number of plant species in the understorey vegetation (tree species $<5 \mathrm{~cm} \mathrm{DBH}$ and other shrubby species) was found to be higher in the CF. This finding was similar to the findings of Webb and Gautam (2001) who observed that the mature, semi-protected forest had a substantially greater basal area while the community forest exhibited a higher density of small diameter trees, which was typical of a young successional forest.

Managed forests were more diverse in plant species than primary forests, and were also more heterogeneous in a study of Sebastia et al. (2005) conducted in Southern Europe. Research carried out in the boreal forests of Canada had suggested that vascular plant species diversity peaked on moderately treated sites (Heusler et al., 2002). Likewise, diversity was rapidly restored through succession in community forests of Nepal although the forest structure was not complex (Webb and Gautam, 2001). However, in this study, tree species were found to be less diverse in the $\mathrm{CF}$ than in the MF although the understorey was more diverse. This might be due to the silvicultural activities carried out by CFUGs based on local knowledge and skills that focused on the promotion of preferred tree density (Acharya, 2003) for economic benefits from tree species useful for timber (Pandey, 2007). The most abundant species in the CF (Castanopsis tribuloides and Quercus glauca) were highly valued by farmers for their high yield of leaves, and as multipurpose trees usable for fodder, fuelwood, agricultural implements and timber (Jackson, 1994).

Silvicultural activities change the tree species composition (Schelhas and Greenberg, 1996) and if they are not carried out with caution, they can jeopardize biodiversity (Putz and Blate, 2001). These findings confirmed that the tree diversity decreased in the CF. There were 40 species of 30 families in the $\mathrm{CF}$ while in the MF, there were only 36 species of 25 families. However, a contradictory finding of this study was the higher vascular plant species richness in the CF. Low impact management mimicking natural disturbances enhances plant diversity (Sebastia et al., 2005) and, therefore, the management that mirrors natural disturbances is recommended to sustain biodiversity (Harvey et al., 2002).

\section{Conclusions}

Silvicultural techniques applied in CF affect forests by altering plant community composition, species richness and distribution, and age class distribution of the trees. From the study it can be concluded that the $\mathrm{CF}$ was changing into less diverse, uniform stands with a low number of species in the tree layer compared to a regular semi-protected forest. However, the overall diversity of vascular plants was maintained by providing proper niches for a rich understorey vegetation. From a biodiversity conservation point of view, special attention must be paid to the maintenance of species diversity in the forest composition when executing silvicultural operations in the community forest. To keep disturbance at an intermediate level would be an appropriate strategy for CF management to achieve the paradoxical twin objectives of i) supplying the basic needs for forest products to the forest users and ii) for maintaining the vascular plant diversity in forest ecosystems.

\section{Acknowledgements}

The authors would like to thank the Gaukhureshwar Community Forest User Group Dhulikhel-1, Kabhrepalanchok. We acknowledge the ITTO 
Fellowship Program, Japan for providing financial support to conduct this study. We also would like to thank Mr. Bimal Acharya, Assistant Research Officer, Department of Forest Research and Survey, Babarmahal, Kathmandu and Mr. Dil Bahadur Purja Pun, Ranger, Department of Forest, Babarmahal, Kathmandu, Nepal for their support during data collection.

\section{References}

Acharya, K.P. 2003. Conserving biodiversity and improving livelihoods: The case of community forestry in Nepal. Paper presented at The International Conference on Rural Livelihoods, Forests and Biodiversity 19-23 May 2003, Bonn, Germany.

HMG/N 2002. Nepal Biodiversity Strategy. Ministry of Forest and Soil Conservation, His Majesty's Government of Nepal.

Haeussler, S., Bedford, L., Leduc, A., Bergeron, Y. \& Kranabetter, J.M. 2002. Silvicultural disturbance severity and plant communities of the southern Canadian boreal forest. Silva Fennica 36(1): $307-$ 327.

Harvey, B. D., Leduc, A., Gauthier, S. and Bergeron, Y. 2002. Stand landscape integration in natural disturbance-based management of the southern boreal forest. Forest Ecology and Management 155(13): 369-385.

Humagain, K. H. 2003. Sustainability of community forest in terms of operational plan implementation: multiple case studies from central and western Nepal. Dissertation submitted to the Institute of Forestry, Trbhuvan University, Nepal for the partial fulfilment of the requirement of the Master of Science in Forestry.

Jackson, J. K. 1994. Manual of Afforestation in Nepal. Forest Research and Survey Centre, Ministry of Forest and Soil Conservation, Nepal Second edition. Volume 2. 824pp.
Padma, T. V. 2007. Community forestry: the regreening of the Himalayas. www.SciDev.Net Accessed on 20 ${ }^{\text {th }}$ April 2008.

Pandey, S. S. 2007. Tree species diversity in existing community based forest management systems in Mid-hills of Nepal. Master thesis, No. 44, Uppsala 2007, ISSN:1653-834X.

Putz, F.E. and Blate, G.M. 2001. Tropical forest management. Conservation Biology 15(1): 7-20

Satyal, P. P. 2004. Country Profile Report- Forestry Sector in Nepal, Forests Monitor, Cambridge (UK).

Schelhas, J. and Greenberg, R. 1996. Introduction: the value of forest patches, In Forest patches in tropical landscapes: J. Schelhas and R. Greenberg (eds.). Island Press, Washington, DC, pp. 15-35.

Sebastia, M. T., Casals, P., Vojnickvick, S., Bogunic, F. and Beus, V. 2005. Plant diversity and soil properties in pristine and managed stands from Bosnian mixed forests. Forestry 78 (3): 297-303.

Sharma, S. K. 2000. Management of Pinus patula stands by the forest user groups in Nepal. A thesis submitted to Georg-August University Goettingen, Germany for the partial fulfillment of the Master in Tropical Forestry.

Tamrakar, P. R. 1999. Biomass Tables for KatusChilaune Forest Type. Department of Forest Research and Survey, Kathmandu, Nepal. Research Leaflet No. 8.

Timberline Forest Inventory Consultants Ltd. 2003. Monitoring plant diversity: Simpson's index and species richness assessment. Canadian Forest Products Ltd. 5162 Northwood Pulp mill Road, Prince George, Canada.

Webb, E. L. and Gautam, A. P. 2001. Effects of community forest management on the structure and diversity of a successional broadleaf forest in Nepal. International Forestry Review 3(2):146-157. 


\section{Annex 1: List of plant species found in the forest at study sites}

\begin{tabular}{|c|c|c|c|c|}
\hline \multirow[b]{2}{*}{ Family } & \multirow[b]{2}{*}{ Species } & \multirow[b]{2}{*}{ Habit } & \multicolumn{2}{|c|}{ Occurrence } \\
\hline & & & $\begin{array}{c}\text { Community } \\
\text { forest }\end{array}$ & $\begin{array}{c}\text { Municipality } \\
\text { forest }\end{array}$ \\
\hline Acanthaceae & Thungbergia coccinea & climber & & $\sqrt{ }$ \\
\hline Ampelidaceae & Leea robusta & Shrub & $\sqrt{ }$ & \\
\hline Anacardaceae & Rhus succedanea & Small tree & $\sqrt{ }$ & $\sqrt{ }$ \\
\hline Asteraceae & Inula cappa & Shrub & $\sqrt{ }$ & $\sqrt{ }$ \\
\hline Asteraceae & Eupatorium adenophorum & Shrub & $\sqrt{ }$ & \\
\hline Betulaceae & Betula alnoides & Tree & $\sqrt{ }$ & \\
\hline Campanulaceae & Lobelia alsinoides & Small tree & & $\sqrt{ }$ \\
\hline Caprifoliceae & Viburnum coriaceum & Shrub & $\sqrt{ }$ & $\sqrt{ }$ \\
\hline Cyperaceae & Cyperus cyperoides & Herb/grass & & $\sqrt{ }$ \\
\hline Cyperaceae & Cyperus rotundus & Herb/grass & $\sqrt{ }$ & $\sqrt{ }$ \\
\hline Dryopteridaceae & Dryopteris atrata & Herb/Fern & $\sqrt{ }$ & $\sqrt{ }$ \\
\hline Ericaceae & Rhododendron arboreum & Tree & $\sqrt{ }$ & $\sqrt{ }$ \\
\hline Ericaceae & Lyonia ovalifolia & Tree & & $\sqrt{ }$ \\
\hline Fabaceae & Indigofera cylindracea & Shrub & $\sqrt{ }$ & \\
\hline Fagaceae & Castanopsis tribuloides & Tree & $\sqrt{ }$ & $\sqrt{ }$ \\
\hline Fagaceae & Quercus glanca & Tree & $\sqrt{ }$ & $\sqrt{ }$ \\
\hline Fagaceae & Castanopsis indica & Tree & $\sqrt{ }$ & $\sqrt{ }$ \\
\hline Gleicheniaceae & Gleichenia glauca & Herb/Fern & $\sqrt{ }$ & $\sqrt{ }$ \\
\hline Lamiaceae & Scuttelaria discolor & Herb/grass & $\sqrt{ }$ & $\sqrt{ }$ \\
\hline Lauraceae & Litsea citrate & Tree & $\sqrt{ }$ & \\
\hline Loranthaceae & Maesa chisia & Shrub & $\sqrt{ }$ & $\sqrt{ }$ \\
\hline Melastomataceae & Osbeckia stellata & Herb & $\sqrt{ }$ & $\sqrt{ }$ \\
\hline Melastomataceae & Melastoma normale & Shrub & $\sqrt{ }$ & $\sqrt{ }$ \\
\hline Meliaceae & Walsura trijuga & Tree & $\sqrt{ }$ & \\
\hline Myricacea & Myrica esculenta & Tree & $\sqrt{ }$ & $\sqrt{ }$ \\
\hline Myrseniceae & Myrsenia rivularis & Tree & $\sqrt{ }$ & $\sqrt{ }$ \\
\hline Myrseniceae & Myrsenia semiserrata & Tree & $\sqrt{ }$ & $\sqrt{ }$ \\
\hline Oleaceae & Fraxinus floribunda & Tree & $\sqrt{ }$ & $\sqrt{ }$ \\
\hline Oleandraceae & Nephrolepsis cordifolia & Fern & $\sqrt{ }$ & \\
\hline Phyllanthaceae & Phyllanthus parvifolius & Shrub & $\sqrt{ }$ & \\
\hline Poyaceae & Digitaria sanguinalis & Herb/grass & $\sqrt{ }$ & $\sqrt{ }$ \\
\hline Poyaceae & Eragrostis tenella & Herb/grass & $\sqrt{ }$ & $\sqrt{ }$ \\
\hline Poyaceae & Athraxon lancifolius & Herb/grass & $\sqrt{ }$ & $\sqrt{ }$ \\
\hline Poyaceae & Arundinaria intermedia & Grass/bamboo & & $\sqrt{ }$ \\
\hline Ranunculaceae & Clematis buchananiana & Herb & $\sqrt{ }$ & $\sqrt{ }$ \\
\hline Rosaceae & Sysygium cumini & Tree & $\sqrt{ }$ & \\
\hline Rosaceae & Robus ellipticus & Shrub & $\sqrt{ }$ & $\sqrt{ }$ \\
\hline Rubiaceae & Loranthus spps. & Tree & $\sqrt{ }$ & $\sqrt{ }$ \\
\hline Smilacaceae & Smilax menispermoides & climber & $\sqrt{ }$ & $\sqrt{ }$ \\
\hline Symplocaceae & Symplococus ramosissima & Shrub & $\sqrt{ }$ & $\sqrt{ }$ \\
\hline Thaeceae & Schima wallichii & Tree & $\sqrt{ }$ & $\sqrt{ }$ \\
\hline Thaeceae & Eurya cerasifolia & Tree & $\sqrt{ }$ & $\sqrt{ }$ \\
\hline Thaeceae & Cleyera ochnacea & Herb & $\sqrt{ }$ & $\sqrt{ }$ \\
\hline Thaeceae & Camellia kissi & Shrub & $\sqrt{ }$ & $\sqrt{ }$ \\
\hline Orchids & species not determined & Epiphytes & $\sqrt{ }$ & $\sqrt{ }$ \\
\hline
\end{tabular}

